\title{
STUDY ON HELICOPTER AERIAL SPRAYING UNDER FIELD CANOLA CONDITIONS
}

\author{
Sehsah, E. M. E. *
}

\section{ABSTRACT}

A field study was conducted to determine influences of spray speed, liquid spray pressure, and height of boom sprayer on effective spray deposition and reduction of drift at canola (Brassica Rapa) flowering stage from AS 350 helicopter. Results of the study show that aircraft height of $2 \mathrm{~m}$ and liquid pressure $460 \mathrm{kPa}$ at spray speed $97 \mathrm{~km} / \mathrm{h}$ reduce effective drift when compared to boom height $10 \mathrm{~m}$ and low liquid pressure $230 \mathrm{kPa}$ for each other fly speed $138 \mathrm{~km} / \mathrm{h}, 115 \mathrm{~km} / \mathrm{h}$ under operating conditions. The result indicated that the amount of drift deposits decreased as target distance downwind increased. The minimum value of the drift at $50 \mathrm{~m}$ distance downwind no spray surface area were $0.006 \mu \mathrm{g} / \mathrm{cm} 2,0.041 \mu \mathrm{g} / \mathrm{cm} 2$ and 0.064 for spray speed $97 \mathrm{~km} / \mathrm{h}, 115 \mathrm{~km} / \mathrm{h}$ and $138 \mathrm{~km} / \mathrm{h}$ under operating pressure $460 \mathrm{kPa}$ and aircraft height $2 \mathrm{~m}$ respectively. The maximum coverage value was $26.8 \%$ at $460 \mathrm{kPa}$ spray pressure compared to $14.7 \%$ at $230 \mathrm{kPa}$ under low spray speed and low aircraft height.

Keywords: Aircraft, helicopter, drift, spray and deposition.

\section{INTRODUCTION}

$\mathrm{H}$ elicopters, also known as rotorcraft or rotary-wing aircraft were first demonstrated for aerial application of crop production and protection materials in1945. Helicopters have experienced continued growth in specialty uses such as forestry, high-value crops, rights-of-ways, and other applications where constraints exist on manoeuvrability or other factors where helicopters have an advantage over fixed-wing aircraft. The Environmental Protection Agency recognized, in proposed product label language for controlling spray drift, that helicopters may be less prone to spray drift in that guidelines for boom lengths for helicopters were set at $90 \%$ of rotor-span,

*Lecturer in Dept. of Agric. Eng. Faculty of Agricultural, Kafr El-Sheikh University, 33516-kafr El-Sheikh, Egypt E-Mail sehsah_2000@yahoo.de 
Compared to $75 \%$ of wingspan for fixed-wing aircraft (Mulkey, 2001; Kirik, 2000; and Carlton and Bouse, 1988). There is continuing interest from all segments of the aerial application industry in better understanding the sources and causes of spray drift and in implementing effective drift mitigation practices, while also maintaining efficiency of operations and efficacy of the applied materials.

It presses a solution to apply aerial spray technique for controlling of forest and agriculture diseases and insect pests. The application of aerial spraying becomes more and more. Over the last three decades, worldwide concern has focused on contamination of water resources.

Runoff and subsurface flow are likely the most important pathways for chronic contamination of surface water habitats with pesticide residues at high $\mu \mathrm{g} / \mathrm{l}$ concentrations (Dabrowski and Shulz 2003). Intense rainstorms in close proximity to application can cause "catastrophic" runoff events with in-stream concentrations (low ng/l) that are acutely toxic to invertebrates and occasionally fish kills. Over the long term, direct contamination of water bodies by spray drift has been associated with only about $10 \%$ of the contaminant loads caused by surface runoff. However, pesticide residues concentrations resulting from spray drift (i.e., $\mu \mathrm{g} / \mathrm{L}$ levels) can be similar to those following heavy rainfalls and thus also constitute acutely toxic exposures (Dabrowski and Shulz 2003). No-spray buffer zones and the encouragement of riparian strips between agricultural land and water bodies have been recommended to simultaneously reduce the likelihood of toxicologically significant spray drift and reduce runoff loading. In review of spray drift and its potential for non-target injury shows the phenomenon, although widely discussed, has not been satisfactorily mitigated despite the many years of training pesticide applicators. Part of the problem is the realization that zero movement is an impossible goal to achieve. Highly concentrated agrochemical residues generated during spray application can move (drift) beyond target foliage (or in some cases soil if a preemergent herbicide or fumigant is used) to non-target receptors including water, plants, and animals. Non-target receptors may be acutely exposed and therefore face the greatest risk of adverse effects 
during and immediately after spray application. In addition to movement of agrochemical residues in turbulent air masses downwind of application, residues can also become concentrated in inversions or stable air masses and be transported long distances. Similarly, agrochemicals can volatilize from plant and soil surfaces in comparatively high concentrations for several days after application. These secondary drift residues also pose a hazard to nearby non-target receptors. The likelihood or risk of an adverse impact will depend directly on the magnitude of exposure. Spray drift can be quantified as a function of surface area deposition relative to downwind distance. The resulting function can be empirically obtained or estimated using both deterministic and stochastic models. Studies have also demonstrated that aerial applications can be made with significantly reduced drift to off-target areas when label instructions are followed. There are a variety of techniques available to aerial applicators to reduce off-target drift, such as swath adjustment, nozzle orientation, and boom height and length (Payne et al. 1990). It has also been reported that spray deposition decreased to less than 10 percent of the application rate in the first 30 meters downwind, and was less than 5 percent at a distance of 200 meters (Riley et al. 1991; and Ganzelmeier, et al., 1995). Results from aerial application trials to assess the validity of the aerial module of AgDrift have been published (Bird et al. 1996, Teske et al. 2002; Anon, 1998). Many of these trials are limited in scope and not commercial scale applications. To date few commercial applications by ground sprayers have been tested to determine model validity. A summary of Spray Drift Task Force (SDTF) aerial studies (Bird et al., 1996) and the SDTF contractor's summary report (Johnson, 1995c) indicate the nearest sampler to the downwind edge of the swath was $8 \mathrm{~m}$ downwind, with no indication of upwind sampler locations. However, the detailed reports by the study contractor (Johnson, 1994, 1995a, 1995b) show a sampler location $30 \mathrm{~m}$ upwind of the upwind edge of the field or upwind edge of the upwind spray swath. Spray deposits on this upwind sampler were generally reported as $<0.022 \mathrm{ng} / \mathrm{cm}^{2}$ on horizontal alphacellulose collectors.

\section{OBJECTIVE}

The objective of this study was to improve the effective spraying area, 
decrease the drift and enhance the deposition of droplets in helicopters aerial spraying field, the spraying speed, nozzle pressure, and height of boom has studied under canola field conditions.

\section{MATERIALS AND METHODS}

Canola crops can be attacked by a number of insect pests during the growing season. Canola harvested before August 15 is unlikely to suffer yield loss from bertha armyworm. Mated female moths prefer to lay eggs on canola in the early flowering stage. Fields in this stage during the egglaying period tend to be hardest hit. A field study was conducted to investigate the effects of helicopter speed, boom height and spray liquid pressure on both spray drift and spray deposition in the last stage of canola plant. The Eurocopter (Formerly Aérospatiale) AS 350 Ecureuil (German. Squirrel) is a light multipurpose helicopter with one engine. It was the first helicopter of Aérospatiale, which was produced on an assembly line. Moreover, with this type of so-called "Starflex" was rotor head introduced a system in which the total number of moving parts, a quarter of the usual construction.

The spray mix was tap water plus $0.25 \%$ volume/volume plus $0.5 \mathrm{~g} / \mathrm{L}$ Characid Brilliant fluorescent tracer in mixing unit at the land as shown in figure 5. The fluorescent tracer was included for drift measurements. The study was conducted in early July 2010 at kleinmaknow, Berlin, Germany. The original plan was to conduct the study with a randomized block arrangement of treatments in three replications. Boom height and aircraft is other important variables that influence spray drift. The pilot controls boom height, height of spray release, or height of flight with considerations for effectiveness and safety of the operation.

\section{TEST LAYOUT AND SAMPLING PROCEDURE}

The deposition and movement of applied material released from the helicopter was measured by flying the helicopter perpendicular to the prevailing wind. Sampling drift were placed perpendicular to the expected wind and at specified distances from the downwind edge of the spray track, as shown in figure 4. There were four parallel sampling lines (A, B, $\mathrm{C}$, and D) for each treatment replication treated under the same weather conditions. The lines were spaced $10 \mathrm{~m}$ apart. At each sampling location, 
Petri dishes were secured horizontally on a free land beside the canola field that was positioned at the runway of each sampling distance. The helicopter made two passes over the described course for each of the four replications of each treatment, always turning on the spray $400 \mathrm{~m}$ before the sampling lines and turning off the spray $400 \mathrm{~m}$ after the sampling lines. One pass was made with the left on the downwind side, and one pass was made with the right on the downwind side. After each replication and allowing sufficient time for the spray material to move downwind, each Petri dish was placed in a labeled carton, stored in carton, and transported to the laboratory for quantification. The Petri dishes were exposed to the sunlight for less than 15 min following an application; therefore, no appreciable degradation of the fluorescent dye (Characid Brilliant fluorescent tracer) would be expected.

Table 1: The technical parameter for Eurocopter (Formerly Aérospatiale) AS 350 multipurpose helicopter

Parameter

Manufacturer

Rotor diameter, $\mathrm{m}$

Hull length, $\mathrm{m}$

Length overall, $\mathrm{m}$

Height, $m$

Min. Tare, $\mathrm{kg}$

max. Off mass, $\mathrm{kg}$

Crew

Top speed, km / h

Cruising speed

Hoveringheight with Ground Effect, m

Service ceiling, $m$

Range , km

Engine, $\mathrm{kW}$

Off power, $\mathrm{kW}$

Continuous Performance, $\mathrm{kW}$
Data

Eurocopter

10.69

10.93

12.94

3.34

1018

2250

1

287

$235 \mathrm{~km} / \mathrm{h}$ (normal), $272 \mathrm{~km} / \mathrm{h}$ (fast)

$>7000$

7010

467 (normal speed without reserve)

1 Turbomeca Arriel 2B1Turbine

632

543 
Drift sampling methods and analysis procedure According to ASAE S561.1 (2004), the sample line was approximately parallel to the wind direction (within $\pm 10^{\circ}$ ). The spray line was perpendicular to the sample line. The sampling surfaces were horizontally located at the top of the soil surface in the downwind. The sampling surfaces were placed for sampling the quantity of pesticide depositing at $1 \mathrm{~m}$ intervals along the sample line. Distances of sampling surfaces were 1, 2, 3, 4 and $5 \mathrm{~m}$ from the last nozzle of the boom along the sample line. Surface area of WSP (water sensitive paper), used for sampling material, was approximately $50 \mathrm{~cm}^{2}(5$ $\times 10 \mathrm{~cm}$ ). This surface area is suitable according to ASAE S561.1 (2004).. In laboratory, samples were extracted using $100 \mathrm{~mL}$ volumes of methanol. The containers were shaken for $1 \mathrm{~h}$ in a water bath with a shaker at room temperature. A $2 \mathrm{~mL}$ fraction of each extract was sealed into a vial and stored in a refrigerator until analysis. The lines were parallel to the flight line and provided a measure of the airborne component of the spray. After each replication, the WSP in Petri dish was collected on rows that were built for this study. The water sensitive paper (WSP) cards were placed in field canola for the horizontal deposition samples and parallel to the sampling drift station. The water sensitive paper cards were collected and analyzed the deposition as above mentioned in drift analysis. Nozzles were mounted on drop booms $25 \mathrm{~cm}$ below the boom; longitudinal axes of the nozzles were nominally parallel to the airstream. Turbo TeeJet ${ }^{\circledR}$ TTI 110-5 drift nozzles was recommended. The 32 number of Turbo TeeJet ${ }^{\circledR}$ TTI 110-5 drift nozzles were mounted for each side of the boom sprayer. All treatments were applied in nominal crosswind with helicopter airspeed of $97 \mathrm{~km} / \mathrm{h}, 115 \mathrm{~km} / \mathrm{h}$ and $138 \mathrm{~km} / \mathrm{h}$ and spray pressure of $230 \mathrm{kPa}, 360 \mathrm{kPa}$ and $460 \mathrm{kPa}$. Pilot was advised to maintain boom height at $2 \mathrm{~m}$ and $10 \mathrm{~m}$. The pilot attempted to hold a height that was operationally realistic, safe, and constant during the release. Effort was made to apply all treatments in spray speed.

Meteorological conditions were recorded during all of the tests and the range of each measurement over all replications. The data presented represent $1 \mathrm{~min}$ averages at the time that the helicopter was spraying. This study was conducted in at a site. The flight line portion of the study was 
conducted in. Weather data including, wind speed and direction, and relative humidity was gathered from canola field locations. The weather station location, a WS2000 was set up on a hill approximately $150 \mathrm{~m}$ above the flight line. A weather station was placed upwind and adjacent to the swath and spray drift sample line. Wind speed and direction, temperature, and relative humidity were recorded at $2 \mathrm{~m}$ heights. The field of canola layout is shown in figure 3 .

\section{DATA ANALYSIS}

All statistical inferences of significant differences refer to the LSD 0.05 levels. The horizontal deposition, data were analyzed using SAS (SAS, 2001). The four sampling lines were considered as fixed effect measurements in the analyses. The completely block design was used to analyzed the data.
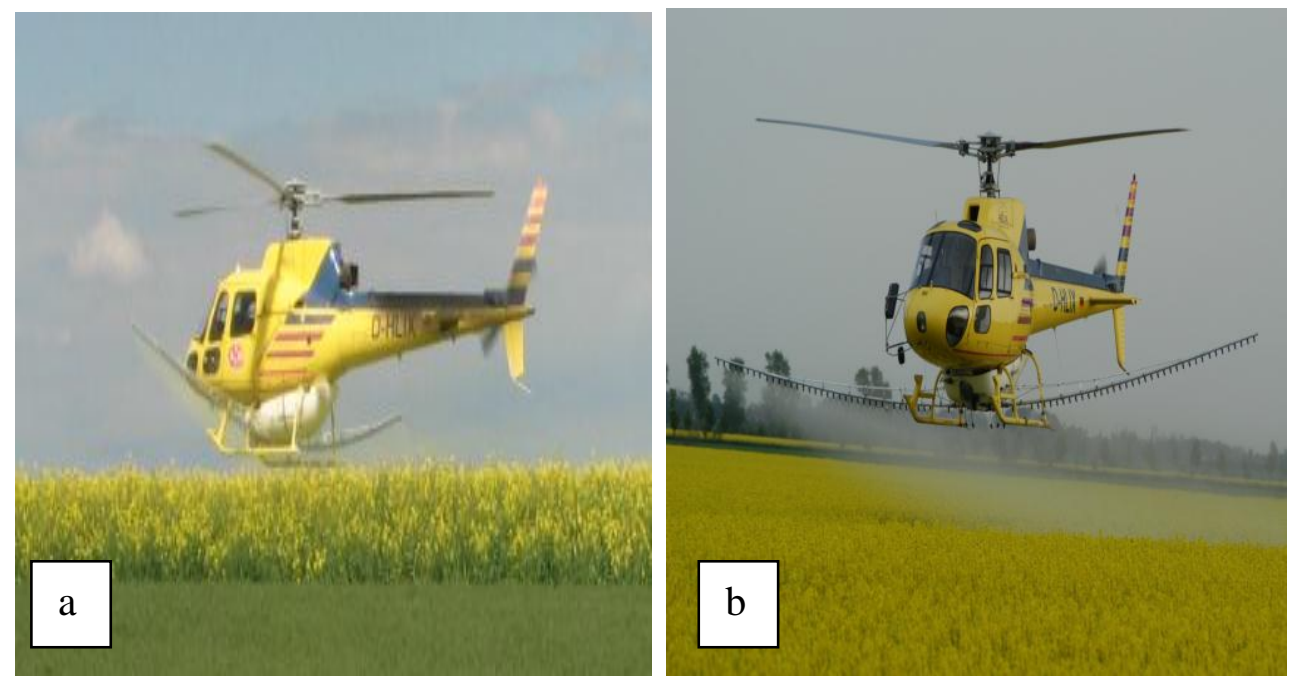

Fig. 2: The Aérospatiale AS 350 multipurpose helicopter operated at $2 \mathrm{~m}$ height (a) and $10 \mathrm{~m}$ height (b) in field canola conditions 


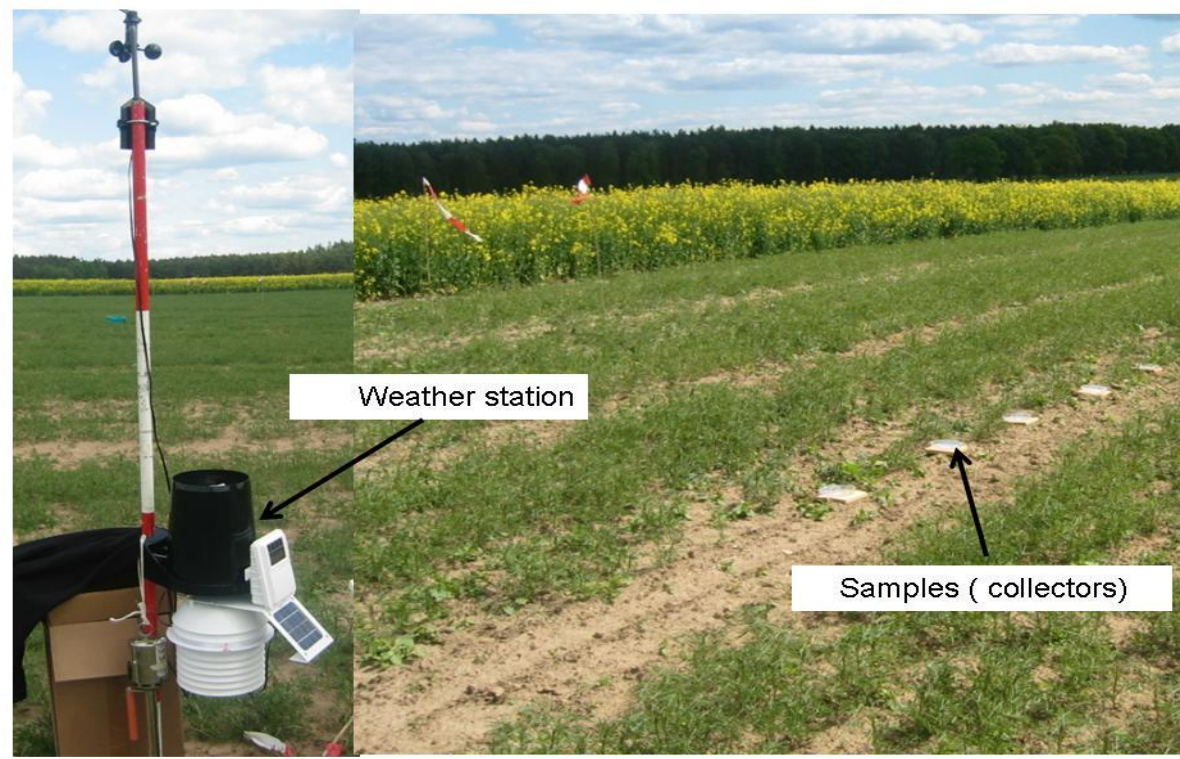

Fig. 3: Display the weather station WS2000 and collectors of samples from the canola field.

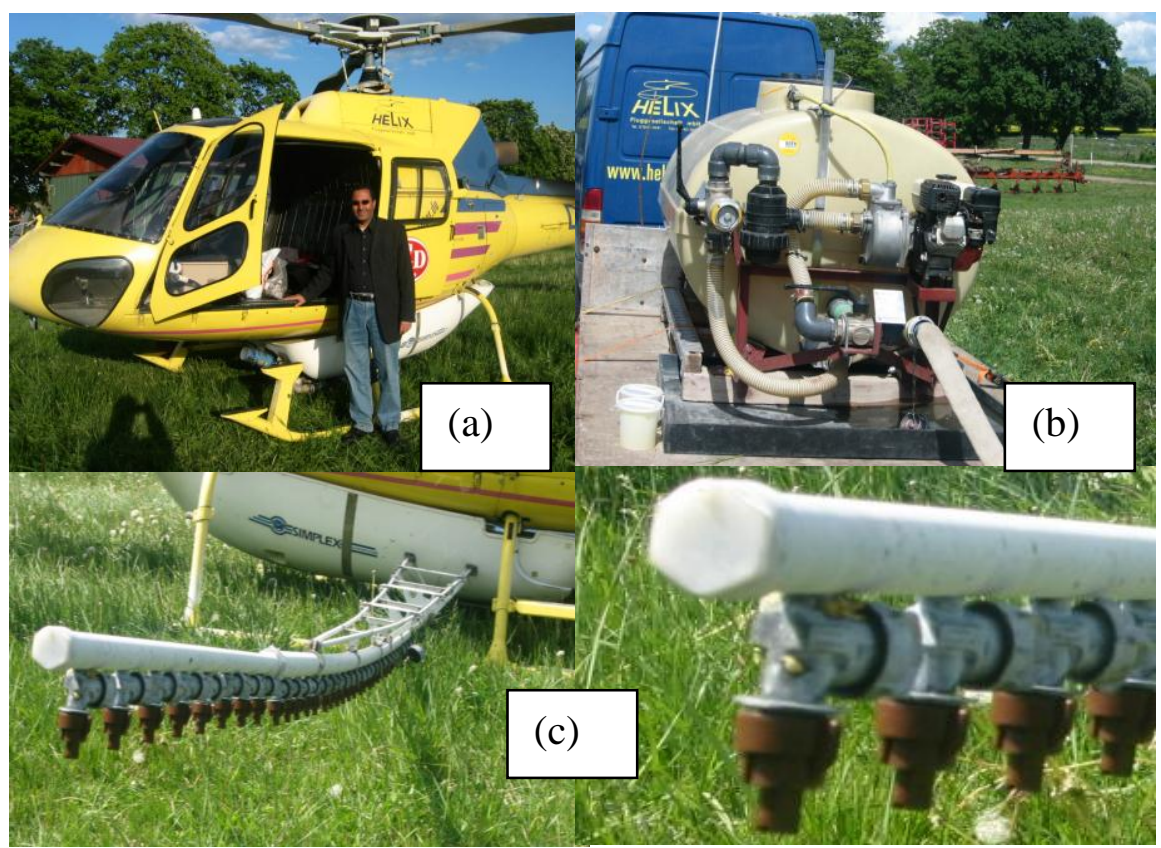

Fig 5: Presented the AS 340 Helicopter (a), maxing unit (b) and nozzles arranged on fixed boom (c). 
Table 2: Listed the weather condition during the treatment of Helicopter spray in canola field condition

\begin{tabular}{|c|c|c|c|c|c|c|c|}
\hline \multicolumn{2}{|c|}{$\begin{array}{c}\text { Temperature, } \\
{ }^{\circ} \mathrm{C}\end{array}$} & $\begin{array}{c}\text { Rel.Hum, } \\
\%\end{array}$ & $\begin{array}{c}\text { Treat day } \\
\text { of spray }\end{array}$ & \multicolumn{2}{|c|}{$\begin{array}{c}\text { Wind } \\
\text { velocity, } \\
\mathrm{m} \mathrm{s}^{-1}\end{array}$} & $\begin{array}{c}\text { Wind } \\
\text { Dir., } \\
\text { Degree }\end{array}$ & $\begin{array}{c}\text { Solar } \\
\text { Rad., } \\
\text { MJ m- }^{2} \mathrm{~h}\end{array}$ \\
\cline { 1 - 1 } Max & Min & & & Max & Min & & \\
\hline 20.9 & 22.1 & 56 & 15.7 .2010 & 5.4 & 3.1 & 87 & 0.983 \\
\hline 23.6 & 23.0 & 58 & 17.7 .2010 & 5.1 & 2.9 & 91 & 0.771 \\
\hline 24.2 & 21.8 & 58 & 18.7 .2010 & 4.6 & 2.7 & 93 & 0.632 \\
\hline
\end{tabular}

\section{Drift deposition}

\section{RESULT AND DISCUSSION}

The efficiency of pest control was likely far from adequate given the limited availability of insecticides, herbicides, and fungicides and the lack of application equipment that could adequately control deposition on foliage. In this context, little attention was given to movement of chemical residues via runoff, leaching, or drift off-target and away from the sprayed field. Thus, consequences of inaccurate and imprecise application were not an issue amidst the struggle to adequately control pests.

The result indicated that the amount of drift deposits decreased as target distance downwind increased as shown in figures 6,7 and 8 . Table 3 listed the mean values of drift deposition at two distance downwind no spray area, $\mu \mathrm{g} / \mathrm{cm}^{2}$ and three operating spray for Helicopter under two height of boom and three spray speed in canola field. The minimum value of the drift at $50 \mathrm{~m}$ distance downwind no spray surface area were 0.006 $\mu \mathrm{g} / \mathrm{cm}^{2}, 0.041 \mu \mathrm{g} / \mathrm{cm}^{2}$ and 0.064 for spray speed $97 \mathrm{~km} / \mathrm{h}, 115 \mathrm{~km} / \mathrm{h}$ and $138 \mathrm{~km} / \mathrm{h}$ under operating pressure $460 \mathrm{kPa}$ and aircraft height $2 \mathrm{~m}$ respectively. On the other hand the maximum value for drift deposition was $0.72 \mu \mathrm{g} / \mathrm{cm}^{2}$ at high liquid spray pressure and aircraft height $10 \mathrm{~m}$ under high spray speed $138 \mathrm{~km} / \mathrm{h}$. 
Table 3: Indicated the mean values of drift deposition at two distance downwind no spray area, $\mu \mathrm{g} / \mathrm{cm}^{2}$ and three operating spray for Helicopter under two height of boom and three spray speed in canola field

\begin{tabular}{|c|c|c|c|c|c|c|}
\hline \multirow{4}{*}{$\begin{array}{c}\text { Operating } \\
\text { pressure, } \\
\mathrm{kPa}\end{array}$} & \multicolumn{6}{|c|}{$\begin{array}{c}\text { Mean values of drift deposition at two distance downwind } \\
\text { no spray surface area, } \mu \mathrm{g} / \mathrm{cm}^{2}\end{array}$} \\
\hline & \multicolumn{3}{|c|}{$10 \mathrm{~m}$ height } & \multicolumn{3}{|c|}{$2 \mathrm{~m}$ height } \\
\hline & $97 \mathrm{~km} / \mathrm{h}$ & $\begin{array}{c}115 \\
\mathrm{~km} / \mathrm{h}\end{array}$ & $\begin{array}{l}138 \\
\mathrm{~km} / \mathrm{h}\end{array}$ & $97 \mathrm{~km} / \mathrm{h}$ & $\begin{array}{c}115 \\
\mathrm{~km} / \mathrm{h}\end{array}$ & $\begin{array}{l}138 \\
\mathrm{~km} / \mathrm{h}\end{array}$ \\
\hline & \multicolumn{6}{|c|}{ At $0 \mathrm{~m}$ distance downwind no spray area } \\
\hline 460 & 0.411 & 0.513 & 0.723 & 0.262 & 0.334 & 0.561 \\
\hline 360 & 0.323 & 0.331 & 0.383 & 0.217 & 0.223 & 0.265 \\
\hline 230 & 0.176 & 0.138 & 0.167 & 0.044 & 0.06 & 0.103 \\
\hline & \multicolumn{6}{|c|}{ At $50 \mathrm{~m}$ distance downwind no spray area } \\
\hline 460 & 0.025 & 0.046 & 0.085 & 0.006 & 0.041 & 0.064 \\
\hline 360 & 0.023 & 0.031 & 0.083 & 0.016 & 0.033 & 0.064 \\
\hline 230 & 0.011 & 0.016 & 0.057 & 0.009 & 0.021 & 0.058 \\
\hline
\end{tabular}

Figures 6,7 and 8 presented the effect of the aircraft height (height of boom spray) and spray speed for helicopter on the drift deposition for different distance downwind distance no spray surface area at constant pressure. It is clear that the increase of spray speed tends to increase the drift fallout for two aircraft height $(2 \mathrm{~m}$ and $10 \mathrm{~m})$ at constant operating pressure $460 \mathrm{kPa}$. The drift deposition values at constant operating pressure $460 \mathrm{kPa}$ was $0.41 \mu \mathrm{g} / \mathrm{cm}^{2}, 0.51 \mu \mathrm{g} / \mathrm{cm}^{2}$ and $0.72 \mu \mathrm{g} / \mathrm{cm}^{2}$ for spray speed $97 \mathrm{~km} / \mathrm{h}, 115 \mathrm{~km} / \mathrm{h}$ and $138 \mathrm{~km} / \mathrm{h}$ and aircraft height $10 \mathrm{~m}$ respectively. The similar trend was also found for other operating pressure $360 \mathrm{kPa}$ and $230 \mathrm{kPa}$. Therefore, the increase of spray speed in helicopter tends to increase the turbulence that gave a high drift for the produced droplet sizes from helicopter sprayer system. On the other hand, the low turbulence gave low drift deposition at the edge of field that produced at low fly speed. As well as, the aircraft height (height of spray boom) has a significant effect on the drift deposition at all distance downwind no spray surface area. The decrease of the aircraft height tends to decrease the drift deposition under all treatment conditions. The drift deposition value were $0.006 \mu \mathrm{g} / \mathrm{cm}^{2}, 0.041$ and $0.064 \mu \mathrm{g} / \mathrm{cm}^{2}$ at aircraft height $2 \mathrm{~m}$ compared with the $0.025 \mu \mathrm{g} / \mathrm{cm}^{2}, 0.046$ and 0.085 at aircraft height $10 \mathrm{~m}$ as shown in table 3 and figures 6,7 and 8 . This result was found at constant operating pressure and for other treatment conditions. 


\section{Drift deposition reduction percentage}

The drift deposition reduction percentage calculated from the following equation:

Drift percentage $=\left[1-\frac{D_{0}}{D_{z}}\right] * 100$

Where:

$\mathrm{D}_{0}$ is the drift deposition at spray surface area (zero distance downwind), and

$\mathrm{D}_{z}, \quad$ drift deposition at no spray surface area (i.e $50 \mathrm{~m}$ distance downwind)

Table 4 indicated that the effect of three influence three parameters (aircraft height, spray speed and operating pressure) on the drift reduction percentage. The result indicated that it could be able to reduce the drift when the helicopter operated at low aircraft, high liquid pressure and low speed. The reducing of spray speed tend tends to reduce the drift. As well as increase the operating spray pressure go to reduce the spray fall out at different no spray surface area. Low aircraft height gave the highest values of drift reduction percent under all treatment conditions. The maximum value of drift reduction percent was $97.7 \%$ and $95.9 \%$ for $2 \mathrm{~m}$ and $10 \mathrm{~m}$ aircraft height at $460 \mathrm{kPa}$ high operating pressure and $97 \mathrm{~km} / \mathrm{h}$ low spray speed respectively. On the other hand, the low drift percent value were $43.7 \%$ and $91.1 \%$ for $2 \mathrm{~m}$ and $10 \mathrm{~m}$ aircraft height spraying at high spray speed and low pressure respectively. The increasing of operating pressure tends to increase the drift percentage as shown in table 4. It could be recommended to spray at high operating pressure and fly at low speed and low height for helicopter under canola field conditions.

\section{Coverage percentage}

Figure 9 presented the effect of aircraft height, spray speed and operating pressure on the coverage percent under canola field conditions. It's clear that increase the operating pressure tends to increase the coverage percent under all treatment conditions. The maximum coverage value was $26.8 \%$ at $460 \mathrm{kPa}$ spray pressure compared to $14.7 \%$ at $230 \mathrm{kPa}$ under low spray speed and low aircraft height. Similar trend was also found at spray speed and aircraft height for helicopter under canola field conditions. As well as, decrease the spray speed and aircraft tends to increase the coverage percentage as shown in figure 9. The effect of operating pressure was significant on drift operating at $2 \mathrm{~m}$ low aircraft height compared with the $10 \mathrm{~m}$ height as shown in table 4. 


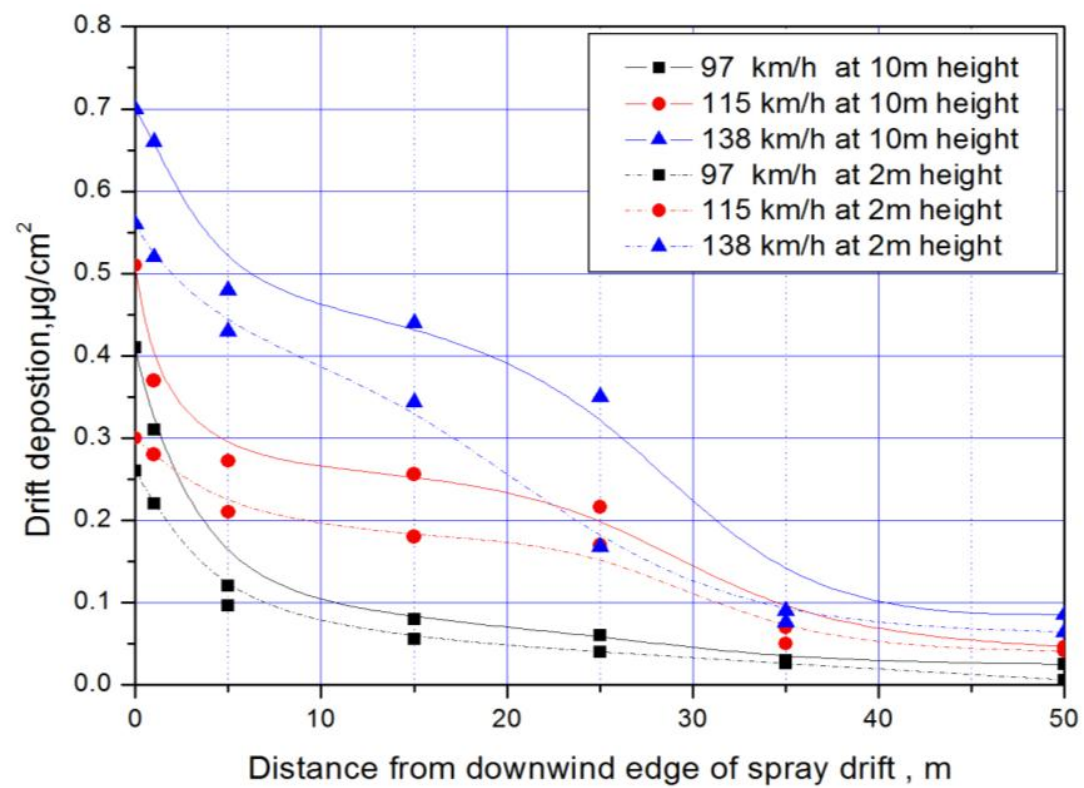

Fig 6: Presented the spray drift deposition at no spray surface areas and operating pressure $460 \mathrm{kPa}$ for AS 340 Helicopter under three spray speed and two aircraft heights.

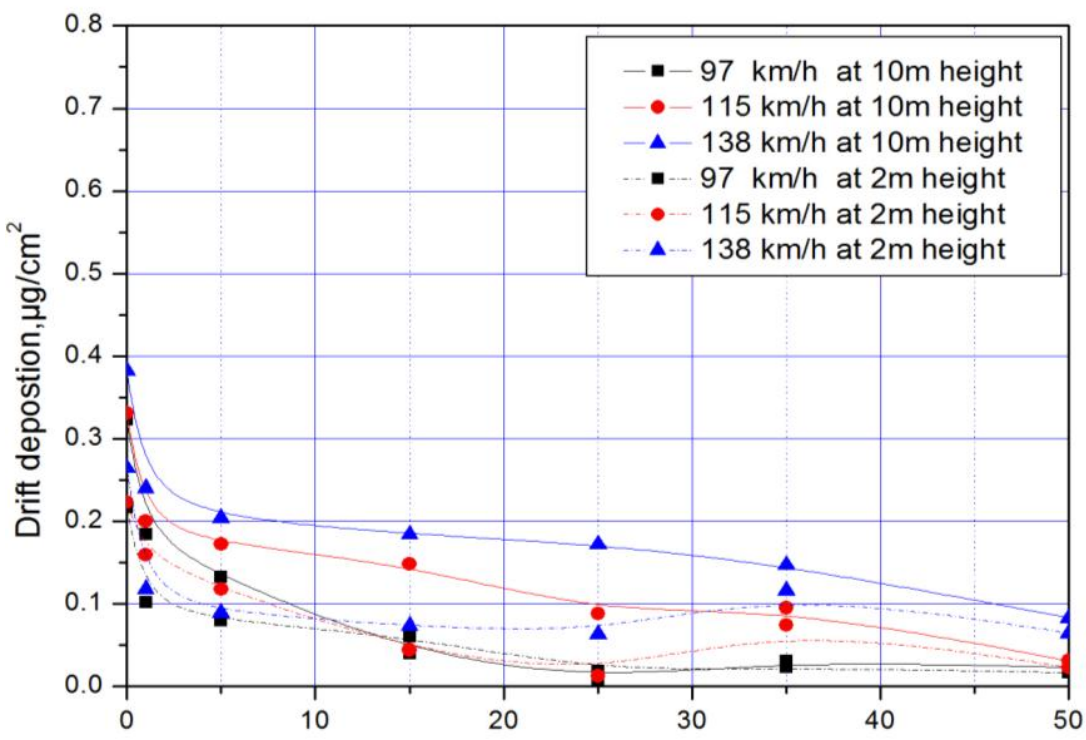

Distance from downwind edge of spray drift, $m$

Fig 7: Presented the spray drift deposition at no spray surface areas and operating pressure $360 \mathrm{kPa}$ for AS 340 Helicopter under three spray speed and two aircraft heights. 


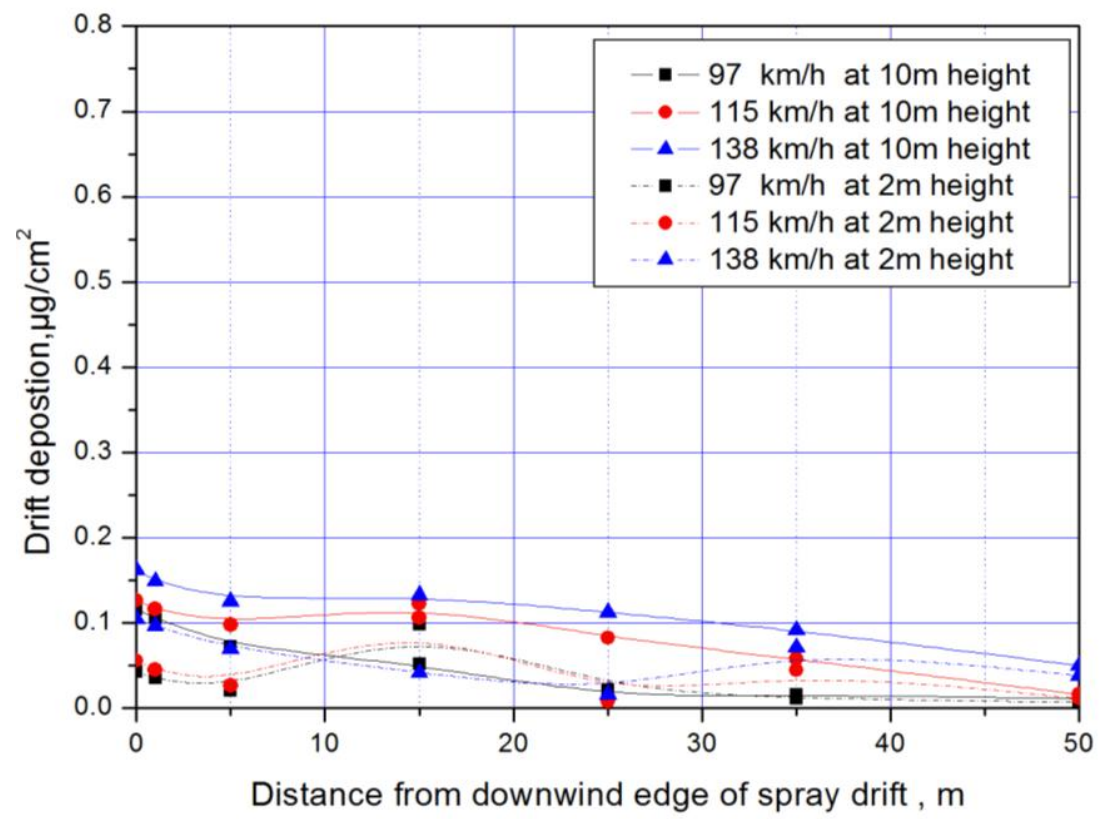

Fig 8: Presented the spray drift deposition at no spray surface areas and operating pressure $230 \mathrm{kPa}$ for AS 340 Helicopter under three spray speed and two aircraft heights.

It may be seen that these three parameters potentially cause significant changes in the drift deposition, drift percentage and coverage percent. Care must be taken to determine helicopter spray speed, operating pressure and aircraft height accurately under field canola conditions. These results are consistent with the ranking importance of these three variables. At the firstly, it should be select an anti drift spray nozzles Turbo TeeJet ${ }^{\circledR}$ TTI 110-5 that produce a low drift to study the effect of other operating parameters.

\section{SUMMARY AND CONCLUSION}

Spray drift is a complex problem. It is depends on equipment design and application parameters. Drift has been historically considered to be the movement of pesticide residues via air masses during and after application. Post application movement of pesticide residues (i.e., after deposition on plants or soil) via volatilization has been distinguished as secondary or indirect drift. On the other hand, off-target or out-of-field drift during application will produce a high concentration of residues that potentially has an immediate or acute effect on non-target receptors. The 
result indicated that the amount of drift deposits decreased as target distance downwind increased. It could be able to reduce the drift when the helicopter operated at low aircraft, high liquid pressure and low speed. The reducing of spray speed tend tends to reduce the drift. As well as increase the operating spray pressure go to reduce the spray fall out at different no spray surface area. The decrease of spray speed and aircraft tends to increase the coverage percentage. The effect of operating pressure was significant on drift operating at $2 \mathrm{~m}$ low aircraft height compared with the $10 \mathrm{~m}$ height

Table 4: Indicated the percentage of drift deposition at three operating pressure for Helicopter under two height of boom and three spray speed in canola field.

\begin{tabular}{|c|c|c|c|c|c|c|}
\hline \multirow{2}{*}{$\begin{array}{c}\text { Operating } \\
\text { pressure. } \\
\mathrm{kPa}\end{array}$} & \multicolumn{4}{|c|}{ Drift deposition reduction , \% } \\
\cline { 2 - 7 } & $97 \mathrm{~km} / \mathrm{h}$ & $\begin{array}{c}115 \\
\mathrm{~km} / \mathrm{h}\end{array}$ & $\begin{array}{c}138 \\
\mathrm{~km} / \mathrm{h}\end{array}$ & $\begin{array}{c}97 \\
\mathrm{~km} / \mathrm{h}\end{array}$ & $\begin{array}{c}115 \\
\mathrm{~km} / \mathrm{h}\end{array}$ & $\begin{array}{c}138 \\
\mathrm{~km} / \mathrm{h}\end{array}$ \\
\hline 420 & 93.9 & 91.0 & 87.9 & 97.7 & 87.7 & 88.6 \\
\hline 360 & 92.9 & 90.6 & 78.3 & 92.6 & 85.2 & 75.8 \\
\hline 230 & 93.8 & 87.2 & 69.1 & 79.5 & 65.0 & 43.7 \\
\hline
\end{tabular}

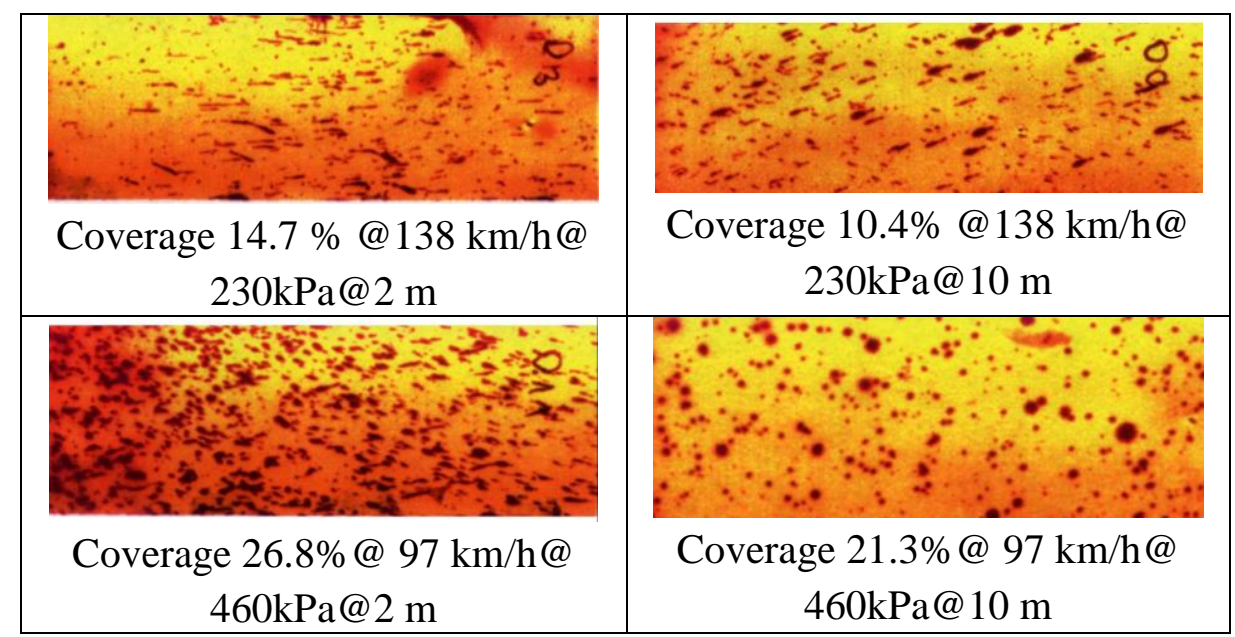

Fig. 7: Indicated the coverage percentage for two heights at low and high operating pressure and spray speed for Aérospatiale AS 350 multipurpose helicopter. 


\section{Acknowledgements}

The authors would like to acknowledge the JKI, Applied Technique Division in Braunschweig, Germany and Research Unit staff for their support and use of the wind tunnel to complete this study. Special thanks are offered to Prof. Dr. H. Ganzelmeier, Mr. S. Nolte, and Mr. L. Oelman in JKI and Dr. R. Heinkel from Lechler Company.

\section{REFERENCES}

Anon. 1998. Helicopter techniques for aerial applications. Bell Helicopter Textron Inc., P.O. Box 482, Fort Worth, Texas 76101.

ASAE Standards, 47th Ed. 2004. St. Joseph, Mich.: ASAE.

Bird, S. L., D. M. Esterly, and S. G. Perry. 1996. Off-target deposition of pesticides from agricultural aerial spray applications. J. Environmental Quality 25(6): 1095-1104

Bird, S. L., S. G. Perry, S. L. Ray, and M. E. Teske. 2002. Evaluation of the AgDISP aerial spray algorithms in the AgDRIFT model. Environ. Toxicol. Chem. 21(3):672-681.

Carlton, J. B. and L. F. Bouse. 1988. Exploring aerial spray sampling with a cylindrical collector. Transactions of the ASAE, 31(4):990-997.

Dabrowski, J. M. and R. Schulz. 2003. Predicted and measured levels of azinphosmethyl in the Lourens River, South Africa:Comparison of runoff and spray drift. Environ. Toxicol. Chem. 22(3):494-500.

Ganzelmeier, H., D. Rautmann, R. Spangenberg, M. Streloke, M. Herrmann, H.-J. Wenzelburger, and H.-F. Walter. 1995. Studies on the spray drift of plant protection products. Heft 305, Blackwell Wissenschafts-Verlag GmbH, Berlin: 111 pp

Johnson, D. R. 1994. Spray Drift Task Force 1992 aerial field study in Texas. EPA MRID No. 432540-01.

Johnson, D. R. 1995a. Spray Drift Task Force 1993 cool season aerial field study in Texas. EPA MRID No. 435358-01.

Johnson, D. R. 1995b. Spray Drift Task Force 1993 hot, humid aerial field study in Texas. EPA MRID No. 435358-02.

Johnson, D. R. 1995c. Drift from applications with aerial sprayers: Integration and summary of 1992 and 1993 field studies. EPA MRID No. 438035-01.

Kirk, I. W. 2000. Aerial spray drift from different formulations of 
glyphosate. Transactions of the ASAE, 43(3):555-559.

Mulkey, M. E. 2001. EPA, OPP-00730; FRL-6792-4. Pesticides; Draft guidance for pesticide registrants on new labeling statements for spray and dust drift. Federal Register 66(163):44141-44143.

Payne NJ, Thompson DG (1992) Off-target glyphosate deposits from Aerial silvicultural applications under various meteorological conditions. Pestic Science 34: 53-59.

Payne NJ, Feng JC, Reynolds PE (1990) Off-target deposits and buffer zones required around water for aerial glyphosate applications. Pestic Science 30: 183-198.

Riley CM, Wisener CJ, Sexsmith, WA (1991) Estimating off-target spray deposition on the ground following the aerial application of glyphosate for conifer release in New Brunswick. J Environ Sci Health B26(2): 185-208.

Teske ME, Bird SL, Esterly DM, Curbishley TB, Ray SL, Perry SG (2002) AgDRIFT $®$ : a model for estimating near-field spray drift from aerial applications. Environmental Toxicology and Chemistry 21(3): 659 671.

SAS. 2001. SAS version 8.2. SAS Institute Inc., Cary, NC, USA.

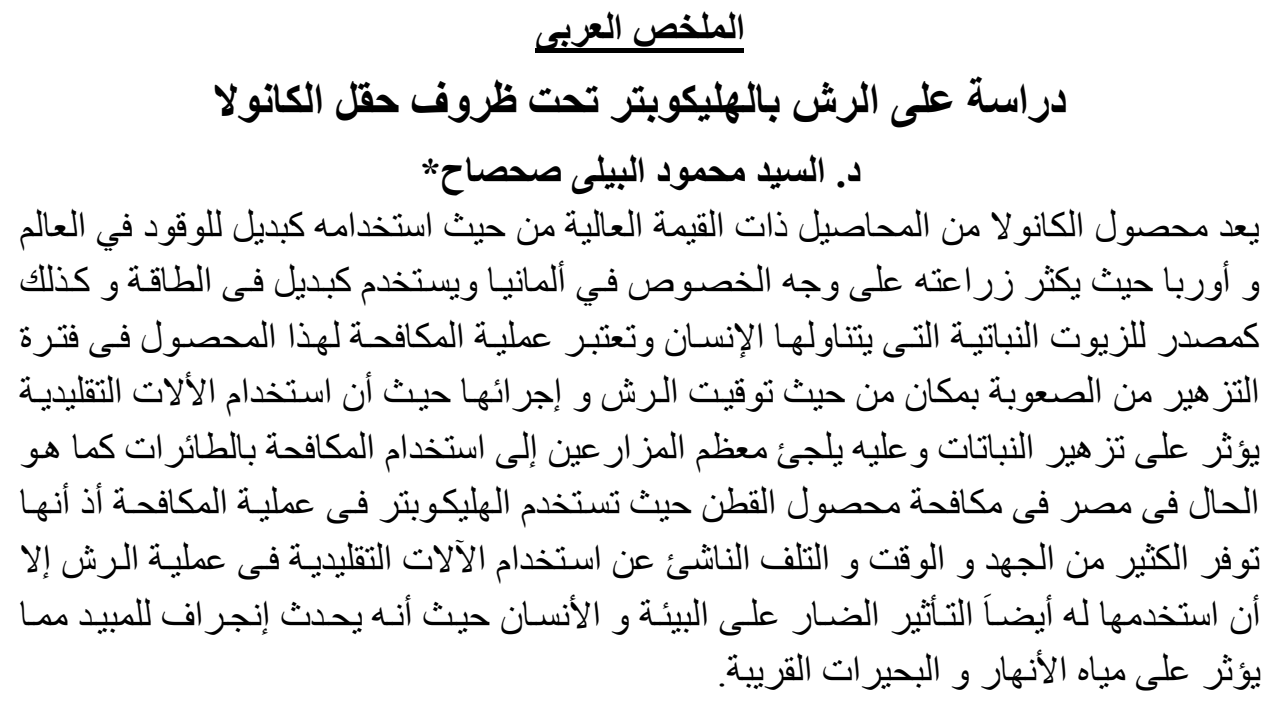

* مدرس بقسم الهندة الزراعيةـ كلية الزراعةـ جامعة كفر الثيخ- مصر. 


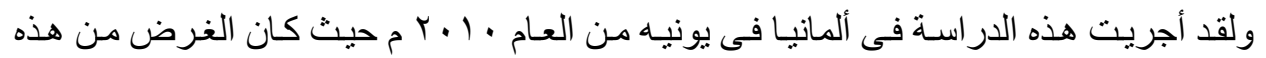

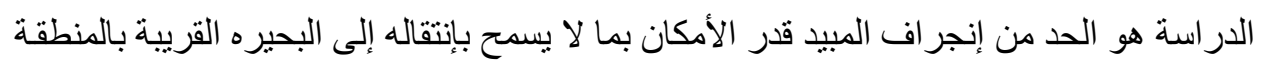

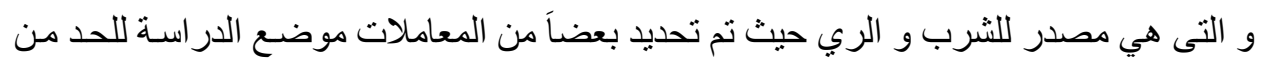

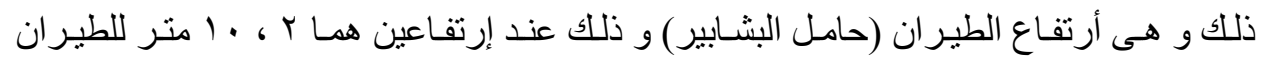

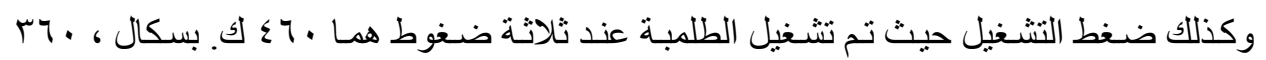

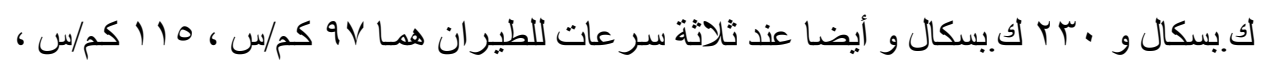

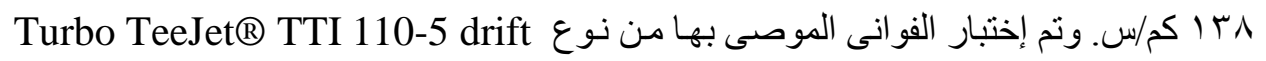
nozzles

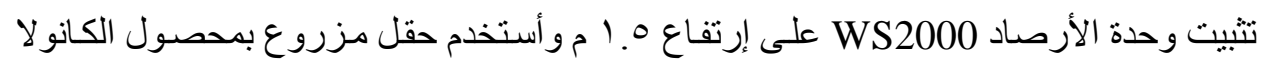

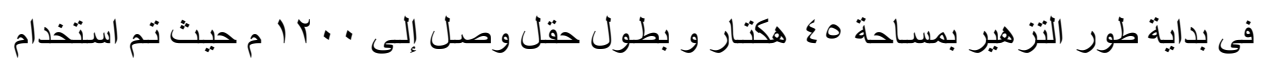
BSF

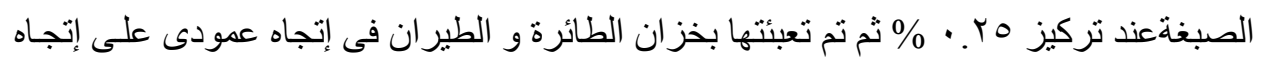

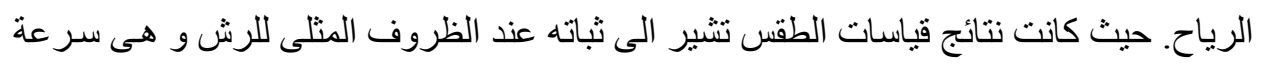
رياح أقل ما يمكن.

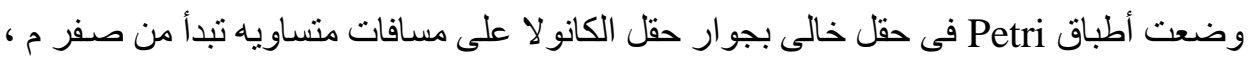

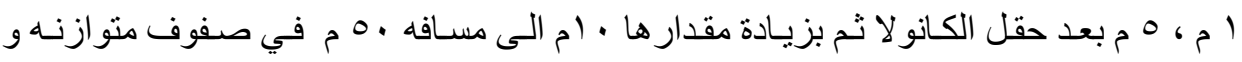

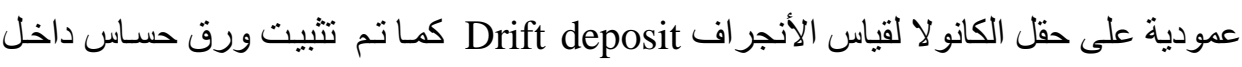
حقل الكانو لا عند النقاط المقابلة لقياس Deposition , Coverage وكفاءة عملية الرش. استخدم جهاز spectrophotometer في تحليل العينات المجمعة عند كل معاملة من معاملات التجربة.

\section{أهم النتائج المتحصل عليها}

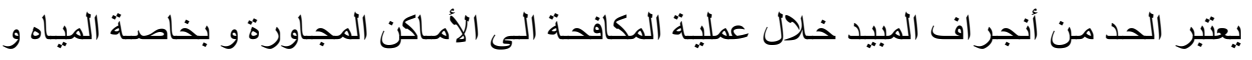

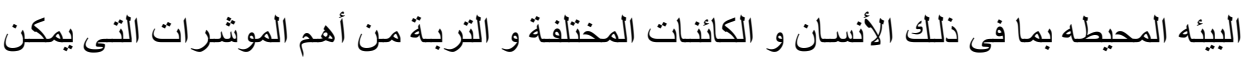

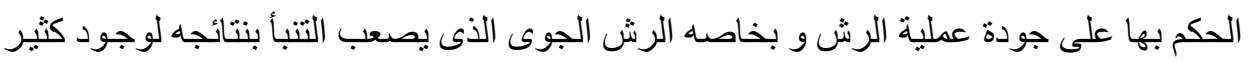
من العو امل و منها العو امل الهندسيه.

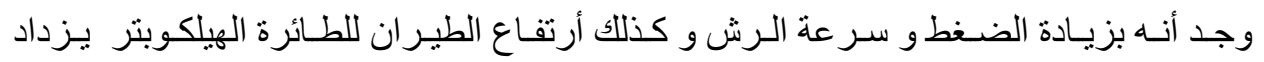

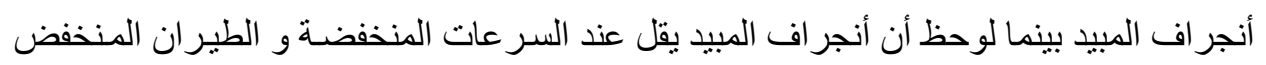

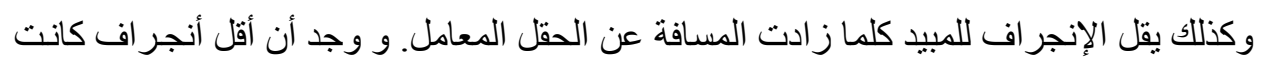




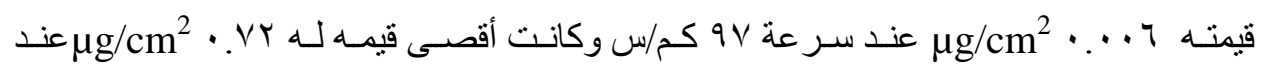

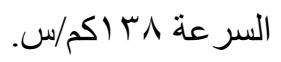

و وجد أيضا من خلال هذه الدر اسـة أنه يمكن زيادة نسبة أنخفاض الأنجر اف من حقل الكانو لا

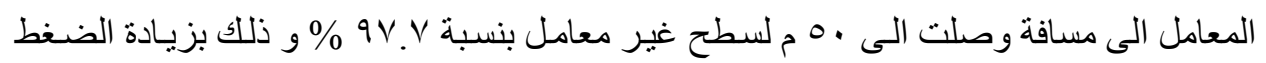

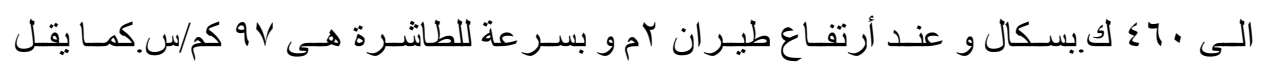
الإنجر اف كلماز ادت المسافه عن منطقة الرش.

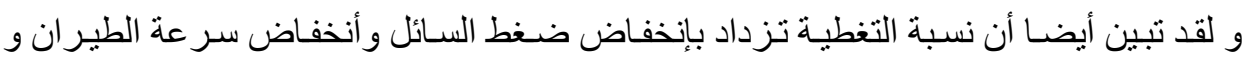

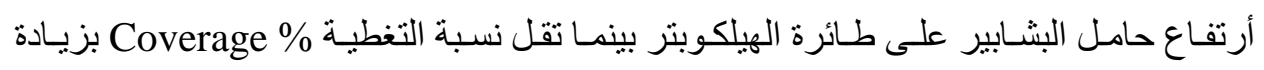

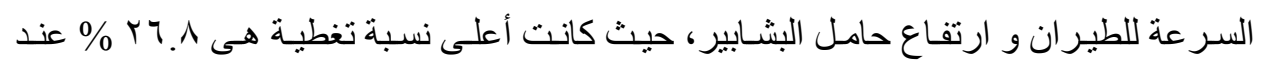

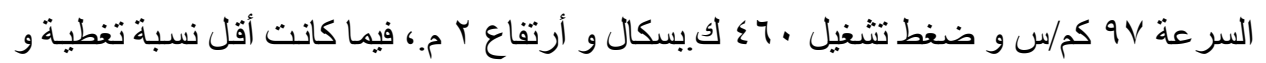

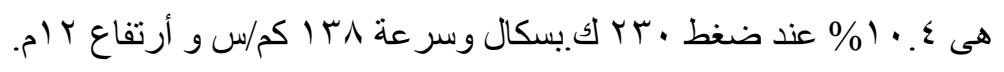

